\title{
Power Systems Protection Course in the Electrical Engineering Programs Offered in Brazil
}

\author{
L. J. S. Kosuhovski, E. A. C. Aranha Neto, and D. Tenfen
}

\begin{abstract}
This paper presents a study of the Power Systems Protection (PSP) course in the Electrical Engineering programs offered in Brazil. The course offered to the undergraduate students has great importance for the future professional of Power System Engineering and should consider aspects to ensure that the future professionals have the necessary skills to carry out the craft of the profession. Initially, the importance of the PSP theme is presented through a compilation of local data (Brazil) regarding the Brazilian Interconnected Electrical System and its impacts on the operation and issues as failures and accidents. The article continues briefly describing the Electrical Engineering programs in Brazil, with current and historical data on Engineering and specifically Electrical Engineering, comparing them with other programs. The official number of Electrical Engineering programs of public and private educational institutions in Brazil and the number of programs that the course is mandatory or optional is also compared. Following, it is presented the characteristics and common subjects addressed in the course syllabus in the different best Brazilian educational institutions according to the Brazilian Institute of Studies and Research (INEP). Finally, the paper is concluded presenting a discussion about the necessity of maintain, increase or decrease the offer of this particular course and the necessity of update its syllabus.
\end{abstract}

Index Terms- Brazilian Electrical System; Electrical Engineering; Power Systems Protection.

\section{INTRODUCTION}

Electricity is widely present in society's daily life and, without it, even simple tasks such as sending an email or watching television can become negatively affected. These and many other actions depend, at some point, on the work of an electrical engineer and this demonstrates the importance of this professional in modern society. It can be said that the electricity becomes more than a need to the modern society, it becomes the key to the economic development [1].

The engineer could be described as a professional who understands exact sciences, assimilates new ideas, tools and technologies and seeks to improve or create products and processes related to his field. Engineering can be described as the precise application of science to provide solutions to

Published on April 13, 2020.

L. J. S. Kosuhovski, Electrical Engineering Department, Federal Institute of Santa Catarina, Brazil.

(e-mail: lehszeskoski@gmail.com)

E. A. C. Aranha Neto* is with the Electrical Engineering Department, Federal Institute of Santa Catarina, Brazil.

(e-mail: earanha@ifsc.edu.br)

D. Tenfen is with the Electrical Engineering Department, Federal Institute of Santa Catarina, Brazil.

(e-mail: daniel.tenfen@ifsc.edu.br) existing problems and this excitement of where engineering can take mankind may be one of the explanations for such a high number of future students. Nowadays there are different engineering programs that work with electricity [2], however the first specialization in this area was Electrical Engineering.

Electrical engineering arose from the necessity to understand electricity and its application. "The roots of electrical engineering are firmly fixed in the science of physics. In 1882, the Department of Physics of the University of Massachusetts (MIT), Cambridge, offered the first optional course in electrical engineering." [3]. In 1902, the Institute set up a separate Electrical Engineering department. Later, this example was followed not only in the country but around the world. In Brazil, the first electrical engineering program was established in 1911 at the Polytechnic School of Rio de Janeiro, currently known as UFRJ (Federal University of Rio de Janeiro). The program original name was Mechanical and Electrical Engineering [4].

The electrical engineering program comprises a curriculum divided into three levels: basic, technical and specific. The basic level is made up of subjects in math, physics and chemistry, among others. The technical level includes subjects such as electromagnetism and electronics and the third contains specific content on electrical engineering considered fundamental to the student's specific academic formation. With a solid base, the electrical engineering program is intended to provide the undergraduate with the necessary skills and knowledge to work with competence and excellence in diverse areas within the scope of electrical engineering [5]-[7].

One of the most important areas of electrical engineering is Power System Engineering, which deals with the generation transmission and distribution of electricity. To keep the system safe and stable is very important to understand and apply Power System Protection (PSP). The PSP subject could be offered as a specific course however this is not compulsory. In this context, the current paper aims primarily to show and discuss the importance of the PSP course and to demonstrate through data the past and current situation in Brazil.

\section{IMPORTANCE OF POWER SYSTEM PROTECTION IN THE BRAZILIAN CONTEXT}

The power systems are getting bigger and more complex due to the demand growth and higher quality requirements. Unfortunately, these complex systems are becoming more vulnerable to natural failures and purposeful outages [4].

Power System Protection is accomplished through a set of equipment aimed at protecting and alerting the system in the 
event of operational failures or abnormalities to provide safety and avoid damage to important equipment. Restricting the spread of power failures and restoring electricity rapidly to minimize the impact on the customer are also aims of PSP.

According to [8], any power system is subject to transitory or permanent defects despite the precautions taken during project elaboration and execution of the installations, even if the strictest rules and recommendations are followed. These defects may have minor consequences or disastrous ones, depending on the protection system in place for that specific installation.

It can be said that protection systems should be used to act rapidly to isolate, avoid or minimize any faults that may signify a danger to, primarily, life and, secondly, equipment. This exemplifies the importance of protection.

The protection occurs through several elements in the system, which are specified based on a protection philosophy. Each equipment possesses its own particularities, functions and level of importance to the power system it is a part of. Relays are used to detect faults in the power system and can be classified according to the way or the quantity that they actuate. As [9] states, "the protection relays, the main equipment in power systems protection, are responsible for rapid withdrawal of the element (equipment, bar or line section) in the case of a short-circuit or abnormal operational function to avoid damage to other parts of the system."

Other components of the protection system are: circuit breakers: the main component used to efficiently interrupt the electrical current and to realize maneuvers in the power networks; current transformers: responsible for adjusting current signal values; potential transformers: responsible for adjusting voltage signal values; lightning arresters and surge protectors: responsible for controlling part of the surges caused by equipment maneuvers or atmospheric discharges in an electric power system. As an alternative to the lightning arresters, horn gap arresters are used. These are inferior to lightning arresters performance-wise and are used particularly in rural systems due to low cost and maintenance; fuse switches: equipment used to provide overcurrent protection caused by overloading and short circuits to avoid damage to the power network. Several other elements comprise the protection system and new equipment are constantly being invented or altered to improve system reliability, lower costs, accidents and improper outages [8].

According to the two latest analysis reports published on forced outages in the transmission system by ANEEL [10][12], the main causes in the Brazilian power transmission network - Brazilian Interconnected System (SIN) are a result of atmospheric discharges, equipment and accessories, fire on lines, human errors, protection, measurement and control, among others. These annually-published reports are part of a strategy devised by the Brazilian Electrical Energy Agency (ANEEL) to inspect, monitor and reduce power outages in addition to conducting a general review of forced outages, identifying the main causes and, later, undertaking corrective measures to make the system safer and more efficient.

The three latest published reports containing this analysis of forced outages in the transmission system contain data corresponding to the period of August 2014 to June 2017. The documents include data from the National Power System Operator (ONS), the transmission agents and an inspection analysis [10]-[12]. The Brazilian Interconnected System (SIN) can be seen in Fig. 1.

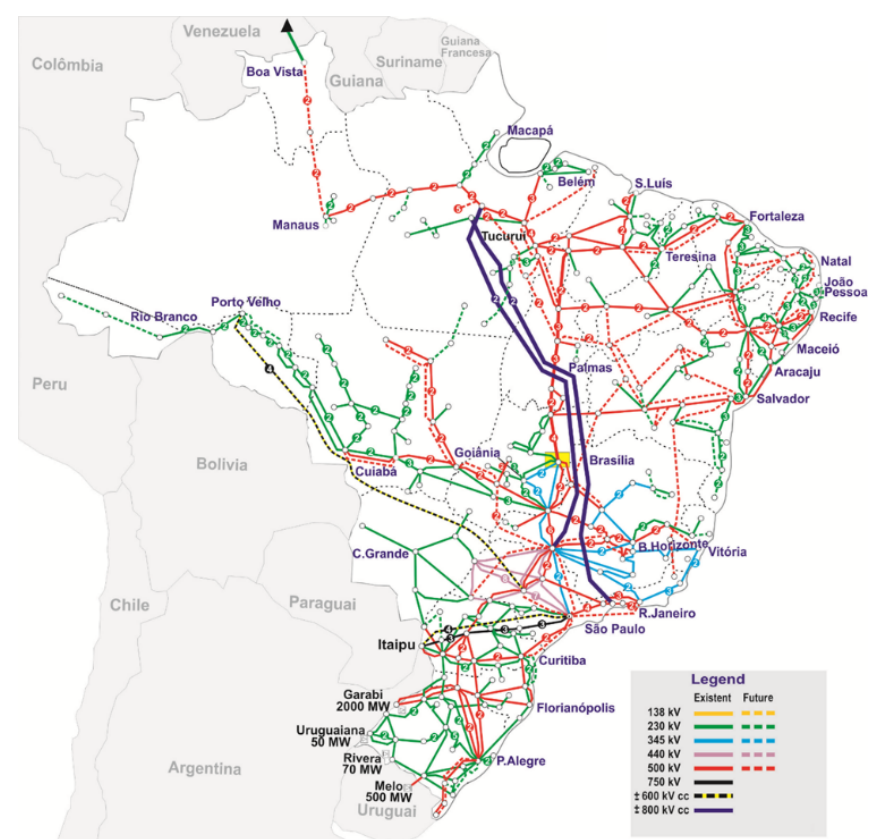

Fig. 1. Brazilian Interconnected System - SIN [13].

According to [10]-[12], 3,271 forced outages, of internal or secondary origin, occurred in $2014 / 2015,3,617$ in $2015 / 2016$ and 3,764 in 2016/2017. The forced outages were in substations and transmission lines belonging to the transmission system.

Unknown causes, human error and protection, measurement and control account for approximately $42 \%$ of the outages. This highlights the need for improvement of the electrical energy transmission system. The causes of forced outages shown in the report of 2014-2017 can be seen in Table I.

TABLE I: CAUSES OF FORCED OUTAGES [10]-[12].

\begin{tabular}{lcccc}
\multicolumn{1}{c}{ Cause } & $\mathbf{2 0 1 4 / 2 0 1 5}$ & $\mathbf{2 0 1 5 / 2 0 1 6}$ & $\mathbf{2 0 1 6 / 2 0 1 7}$ & $\begin{array}{c}\text { Change over } \\
\text { last cycle }\end{array}$ \\
Undetermined & 957 & 886 & 691 & $-22,01 \%$ \\
Atmospheric discharge & 486 & 614 & 683 & $11,24 \%$ \\
Equipment and Accessories & 375 & 428 & 416 & $-2,80 \%$ \\
Burning / Fire under the Line & 346 & 394 & 429 & $8,88 \%$ \\
Human Errors & 480 & 394 & 440 & $11,68 \%$ \\
Protection, Measurement and Control & 201 & 239 & 250 & $4,60 \%$ \\
External Interference (Objects) & 73 & 175 & 232 & $32,57 \%$ \\
AC-DC Wiring & 129 & 168 & 103 & $-38,69 \%$ \\
Vegetation & 148 & 162 & 210 & $29,63 \%$ \\
Natural Phenomena & 76 & 157 & 310 & $97,45 \%$
\end{tabular}

If we compare the ANEEL reports from 2015/2016 and $2016 / 2017$ [11]-[12], unknown causes decreased $22 \%$ in forced outages, human error increase $11 \%$ and protection, measurement and control increase 5\%. Here it becomes clear that, despite corrective measures and actions, the number of forced outages related to protection, measurement and control did not decrease the following year, showing that much still needs to be done to improve the safety and efficiency of the Brazilian power system.

As regards the reports discussed above, some types of errors could also be linked to the lack of adequate 
protection, measurement and control. A well-monitored system which enjoys a good protection philosophy and control could have a reduction in problems listed as undefined, human errors, equipment failure or others.

These outages cause many problems and damage to SIN and leave thousands of consumers without electricity. To better map the outages, ANEEL divided the data by regions and transmission system operators to ascertain the reasons for the reoccurring outages and seek effective corrective measures.

In response to the number of outages occurring in SIN and because one of the main causes is improper PSP operation, the Committee for Monitoring the Energy Sector (CMSE) stipulated that ONS and ANEEL propose strategies in partnership with companies from the electric energy sector to improve PSP efficiency and security and reduce the number of forced outages occurring year after year. Consequently, ANEEL invited companies with the highest incidents of outages through protection failures, human errors and unknown causes to provide information and present an Improvement Plan. Some task groups were also created to conduct a more in-depth analysis of the resulting problems and propose solutions.

\section{THE ELECTRICAL ENGINEERING PROGRAM IN BRAZIL}

The Brazilian population is growing every year and the number of students interested in higher education continues to rise. Technical reports from the Brazilian Institute of Studies and Research (INEP) [15] show that in 2000, the number of Brazilians who enrolled for higher education was approximately 2.7 million which represents almost $1.5 \%$ of the population. In 2013, this number increased to 7.3 million, almost $3.6 \%$ of the population, in the year 2016 there was another rise in the number of enrolments for higher education, with about 8 million people, representing $3.9 \%$ of the population. Last higher education census points that in 2018 the rise in the enrolments numbers continues to rise, but in a more moderate way, with about 8.4 million people, corresponding to $4 \%$ of the Brazilian population [15].

Despite the growth in the number of places available at higher education institutions over the years, it remains clear that this figure does not match the correct number of interested people as the number of enrolments remains much higher than the number of university entrants. According to [15], in 2016 there were more than 8 million enrolments, but less than 3 million entrants. In 2018, there were 8.4 million enrolments, but only 3 million entrants.

According to INEP data, interest in the different types of engineering has seen a gradual increase in the last few years. In the higher education census of 2016 and 2018, it is possible to verify that the that were 206,646 and 307,753 entrants in engineering courses, respective. Electrical and Electrothenical Engineerging represent about $17 \%$ of the entrants in 2016, and $22 \%$ in 2018 .

Among the various branches of engineering, electrical engineering is one of the programs with the highest number of students achieving their degree, according to data obtained from INEP. Table II shows the 5 programs from which the highest number of students graduated in engineering in 2000, 2013, 2016 and 2018. If we compare this with the data from Fig. 2, we can see how the increase in the number of entrants culminated in the increase of students who completed the course [15].

TABLE II: THE 5 ENGINEERING PROGRAMS WITH THE HIGHEST NUMBER OF STUDENTS WHO ACHIEVED THEIR DEGREE IN BRAZIL [14].

\begin{tabular}{|l|c|c|c|c|}
\hline \multicolumn{1}{|c}{ Courses } & $\begin{array}{c}\text { Number of } \\
\text { degrees achieved } \\
\text { in 2000 }\end{array}$ & $\begin{array}{c}\text { Number of } \\
\text { degrees achieved } \\
\text { in 2013 }\end{array}$ & $\begin{array}{c}\text { Number of } \\
\text { degrees } \\
\text { achieved in } \\
\mathbf{2 0 1 6}\end{array}$ & $\begin{array}{c}\text { Number of } \\
\text { degrees } \\
\text { achieved in } \\
2018\end{array}$ \\
\hline Civil Engineering & $1^{\circ} 5.220$ & $1^{\circ} 13.619$ & $2^{\circ} 43.521$ & $1^{\circ} 50.872$ \\
\hline $\begin{array}{l}\text { Electrical } \\
\text { Engineering }\end{array}$ & $2^{\circ} 2.889$ & $3^{\circ} 6.782$ & $4^{\circ} 10.582$ & $4^{\circ} 11.945$ \\
\hline $\begin{array}{l}\text { Production } \\
\text { Engineering }\end{array}$ & $3^{\circ} 2.869$ & $2^{\circ} 12.181$ & $1^{\circ} 126.100$ & $2^{\circ} 21.916$ \\
\hline $\begin{array}{l}\text { Mechanical } \\
\text { Engineering }\end{array}$ & $4^{\circ} 1.799$ & $4^{\circ} 6.620$ & $3^{\circ} 13.116$ & $3^{\circ} 18.021$ \\
\hline $\begin{array}{l}\text { Chemical } \\
\text { Engineering }\end{array}$ & $5^{\circ} 1.014$ & $5^{\circ} 2.959$ & $5^{\circ} 4.838$ & $5^{\circ} 6.066$ \\
\hline
\end{tabular}

This growing demand contributed to the growth in the number of electrical engineering programs offered in the country and, as a result, MEC currently has 622 registered institutions that offer the electrical engineering program. The majority of these are private or non-profit organizations $(81.5 \%)$ [15].

In Brazil, the electrical engineering undergraduate students usually receive the generic degree of electrical engineering despite the specialization of the program, as power system or electronics. The same happens in USA and Canada programs as reported in [19]. In the past, the degree certificate was enough to the Federal Council of Engineering and Agronomy (CONFEA), institution responsible for regulating the profession in Brazil, to assign multiple specific assignments for this professional. Today there is a task force in CONFEA to specify the assignments based on the syllabus and studying hours that the student attended during the program [20].

Other important issue on the electrical engineering programs in Brazil is the curriculum composed of at least $30 \%$ of basic formation, $15 \%$ of technical syllabus and a minimum of 160 hours of supervised internship [21]. The minimum course time is 3,600 hours and the previous percentage are based on this time. The remain 1,820 hours could change depending on the university, although most of the electrical engineering programs maintain at least $60 \%$ to the basic and technical formation.

\section{POWER SYSTEMS PROTECTION COURSE}

The Power Systems Protection (PSP) course is often offered to the student who complete previous studies on Power Systems as power flow methods, symmetrical and asymmetrical short-circuits and power system stability or these syllabi are include at the course.

In short, the offers in the electrical engineering programs in Brazil content the following syllabus: characteristics of protection and measurement equipment related to protection; types of protection, examples, protection relaying, transmission lines protection, distribution network protection, generation protection, transformers protection and ways to coordinate PSP, among others.

This data was compiled from a syllabus analysis of 40 institutions which obtained the best evaluations from the Brazilian Examination of Student Performance (ENADE), with overall scores of 5 and 4 out of a maximum of 5 .

Of these institutions, $32.5 \%$ offer the subject in the 
curricular matrix and, following further research, it was noted that the PSP syllabus and bibliography are similar in most universities. The most frequent bibliography titles are G. Kindermann. Proteção de sistemas elétricos de potência (Power System Protection) vol. I, II e III [27]; A. C. Caminha. Introdução à proteção dos sistemas elétricos (Introduction to Power System Protection) [28]; C. R. Mason. The art \& science of protective relaying G\&E [29]; W. A. Elmore. Protective relaying theory and applications [30]; J. Mamede Filho, D. R. Mamede. Proteção de Sistemas Elétricos de Potência (Power System Protection) [31].

Due to the large number of institutions which offer the course, small modifications between one syllabus and another can be observed. One example is the Catholic University of Santa Catarina, a recognized MEC institution with an ENADE score of 4. Here, the subject is divided into two components: Protection of Electrical Machines and Power Systems. In addition to this content on PSP, the student will also learn the basics of electrical machines protection, three-phase short-circuit calculation and symmetrical components [22]. The basic tenets of the PSP course remain to ensure that, by completion of the course, the students will have developed the skills to identify PSP behavior and know how to specify and coordinate equipment and procedures related to protection in its different operations.

At the University of Arizona, it is used a physical teaching platform to teach digital relay operations. According to [23], "The objective of the platform is to provide opportunities for the users to practice on power protection and relaying systems. The laboratory equipment is installed on an experiment desk, which consists of four major parts: a three-phase equivalent distribution network, a fault generating section, monitoring equipment systems and digital relay protection systems. The users are expected to learn the programming of digital relays, the circuit connections of the monitoring equipment systems, the operation of the fault generating section and the analysis of fault protections with assistance of relay-computer interface. The platform is capable of performing multi-type protection schemes, such as, directional overcurrent protection and pilot protection. In addition to traditional protection schemes, communication technology is also included in the experiments to equip students with adequate knowledge of automation operation in smart grid." Thus, it can be said that the course can be delivered with a practical approach, and not only theoretical.

\section{OFFER OF THE POWER SYSTEMS PROTECTION COURSE}

The significant increase in the number of programs offered and, notoriously, the number of electrical engineering students according to INEP data, are constantly concerned with the quality of future electrical engineers. Ensuring excellently qualified Brazilian students is the first step in the search for quality and excellence in the area. "Among the alternatives to updating the education process in electrical engineering, the curricular adjustments are a relevant line of research. In fact, electrical engineering education has always been an adaptive process throughout history. It has experienced several adjustments based on demands from society and influenced the latter through its innovations and advances" [24]. With solid skills and knowledge of PSP, new techniques and methodologies can emerge to improve the current framework reported by ANEEL, as outlined in the second section of this paper.

In public institutions, $53.9 \%$ of the universities or institutes offer the course in the curriculum, either as compulsory $(58.1 \%)$ or optional $(41.9 \%)$. In private institutions, the percentage of programs with this course in the curriculum is slightly lower, approximately $43.8 \%$, but, in most institutions, this course is compulsory (94.6\%) [15].

Although the number of institutions that do not offer the PSP course is generally higher when we consider private and public institutions, the difference is slight. It is hoped that new lines of thinking and changes regarding not only student academic knowledge during the university program but also the development of a future skilled professional, can be improved, thus improving the quality of teaching, qualification of the undergraduate professional and quality in the workplace.

In Fig. 2, a comparison is made among all the electrical engineering programs currently running, in public and private institutions and shows the percentages of those who have or do not have PSP as a curricular unit in the curriculum. Data on whether the course is compulsory or optional at these institutions is also provided.

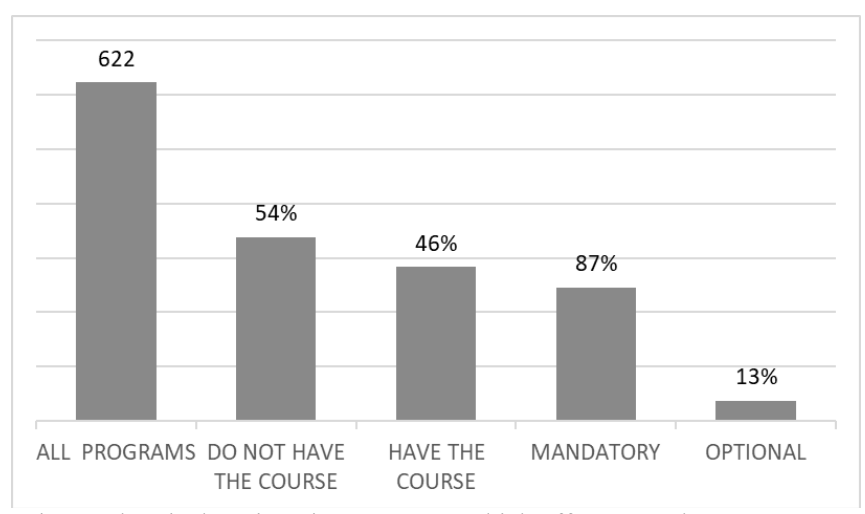

Fig. 2. Electrical engineering programs which offer or not the PSP course [15].

According to [25], there is one engineer for every 2,000 inhabitants in China, one engineer for every 2,300 inhabitants in Germany, one engineer for every 6,000 inhabitants in Brazil and, in Argentina, there is 1 for every 6,600 inhabitants. Despite the great populational and territorial differences, almost the same number of engineers per inhabitant graduate in Argentina as they do in Brazil. This shows how the national expansion of university education is necessary when compared to countries like China and Germany.

As authors in [25] states, there are 25 electrical engineering programs in Argentina, in public or private institutions and, of these, only one institution offers PSP course as compulsory, three institutions offer it as an optional course and two institutions as an elective course. The authors point out that offering the course as elective does not solve the problem as, in this case, the content is superficial and does not provide the necessary knowledge.

Fig. 3 shows a comparison between all the electrical engineering programs currently running in Argentina at both 
public and private institutions. It is possible to observe the percentage of these courses that offer or not the curricular unit PSP in the curricular matrix and whether this is compulsory or optional.

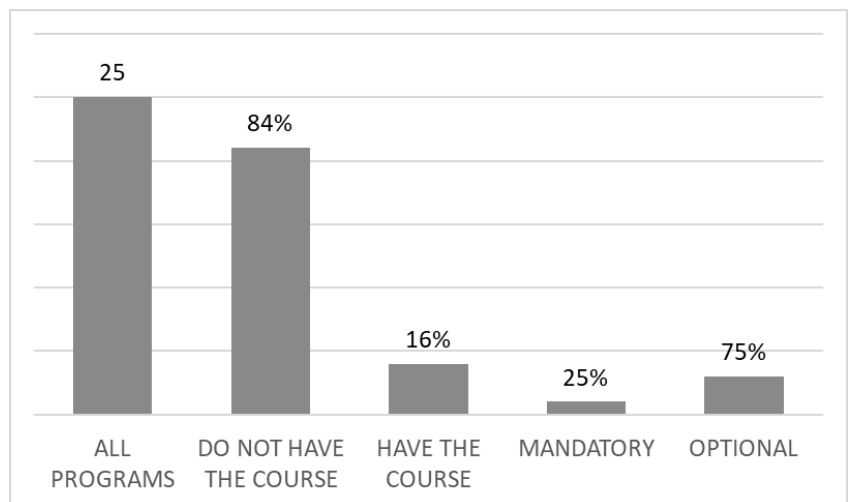

Fig. 2. Electrical engineering courses in public and private institutions that offer or not the CU PSP in the curricular matrix in Argentina [25].

If we compare the data from Brazil (Fig. 2) with the data shown in Fig. 3, clear differences can be seen and, although Brazil presents better percentages, future improvements must still be recommended to the institutions that do not offer PSP course as a curricular unit, especially in programs that focus on power systems. This is to ensure continuous strides are made in the quality of education, development of future engineers and, consequently, in the protection systems. This would result in safer and more efficient energy transmission and distribution systems in Brazil.

Improving education is a worldwide concern, and several countries conduct research related to this purpose. In [26] is presented a report on the Electrical Engineering education resources of universities and colleges in the North America. In this report, data were collected from 115 institutions, of which 107 were from the USA and 8 from Canada. The authors collected data about faculty, research and funding activities, graduate enrolment and course enrolment, among others.

The authors in [1] presented a report with data collect from 75 North America institutions. This study tried to answer these two main questions: if the institution offers regularly a PSP course and if the institution offers the theme in another course. The results obtained were: from the 75 institutions, 50 institutions responded the questioning, and among those, 21 offer the PSP theme inside other courses and the other 29 offer one or more PSP courses. The main emphasis of these courses is failure calculation, relay adjustments and components coordination. The PSP subject is also offered in post-graduate programs.

It is worth mentioning that papers with this subject are very important, as it is possible to verify the weak points in an educational system, with the objective to improve it, proposing to the future professionals a solid basis in the basic principles of techniques and components, offering the needed competences.

The increase of Distributed Generation (DG) causes a whole change of paradigm in the protection system of the distribution networks [32]-[33], so it is extremely important that future professionals are up to date with new technologies and ways of network operation.

\section{CONCLUSION}

The electrical engineer is of extreme importance to contemporary society and we depend on these professionals constantly to ensure we have the necessary electricity to go about our daily lives. As a result of demographic growth and easier access to higher education, we have seen a significant rise in the number of students interested in studying at higher education institutions in Brazil. Subsequently, the number of public and private institutions has also increased, as has the number of students completing their course. Among the engineering programs, electrical engineering figures in the top three with the highest number of degrees achieved, raising some concerns regarding the quality of these students and whether they have the necessary skills to work in this field, both safely and efficiently.

The Power Systems Protection course is fundamental in the development of a power engineer as it presents the equipment used in a protection system, its purpose and uses, and clarifies the functions of this kind of system in an electrical power system.

Despite the importance of the PSP course in the development of undergraduates, more than half of the postsecondary education institutes in Brazil do not offer this subject, even as an optative, which creates a gap in the knowledge of these students and future professionals in Electrical Engineering.

The first step towards guaranteeing competent professionals is by providing quality education, whether at primary or university level, and proposing access to all information and skills to develop the ability to work safely and efficiently, to prioritize life and safety as well as seeking innovations to improve society and its environment.

\section{ACKNOWLEDGMENT}

The authors would like to thank the Brazilian National Council for Scientific and Technological Development (CNPq) and the Federal Institute of Santa Catarina (IFSC) for the research support.

\section{REFERENCES}

[1] S. Brahma, J. De La Ree, J. Gers, A. A. Girgis, S. Horowitz, R. Hunt, M. Kezunovic, V. Madani, P. McLaren, A. G. Phadke, M.S. Sachdev, T.S. Sidhu, J. S. Thorp, S.S. Venkata, T. Wiedman. "The Education and Training of Future Protection Engineers: Challenges, Opportunities, and Solutions", IEEE Trans. on Power Delivery, v. 242, pp. 538-544, 2009. DOI: 10.1109/TPWRD.2009.2014029.

[2] A. S. Leger, "A Multidisciplinary Undergraduate Alternative Energy Engineering Course," IEEE Trans. on Education, vol. 62, no. 1, pp. 34-39, Feb. 2019. DOI: 10.1109/TE.2018.2844811.

[3] F. C. Berry, P. S. DiPiazza, S. L. Sauer, "The future of electrical and computer engineering education" IEEE Trans. on Education, v. 46, pp. 467-476, 2003. DOI: 10.1109/TE.2003.818757.

[4] UFRJ. Federal University of Rio de Janeiro. Pedagogical Project of the Electrical Engineering Course. Rio de Janeiro, RJ, 2009. Available:

http://www.dee.ufrj.br/documentosDEE/projeto\%20pedagogico/Proje toPedagogicoEletrica2007.0.pdf. (in portuguese).

[5] IFSC. Federal Institute of Santa Catarina. Pedagogical Project of the Electrical Engineering Course. Florianópolis, SC, 2017. Available: http://florianopolis.ifsc.edu.br/images/stories/ppc/graduacao/ppc_eng eltrica dae cf ifsc 2014.10 v2.4\%20-\%20publicao.pdf. portuguese)

[6] IFSC. Federal Institute of Santa Catarina. Pedagogical Project of the Electrical Engineering Course. Joinville, SC, 2017. Available: http://cs.ifsc.edu.br/portal/files/JOINVILLE_ENG_ELETRICA_AO_ PPC 906.pdf. (in portuguese) 
[7] UFSC. Federal University of Santa Catarina. Pedagogical Project of the Electrical Engineering Course. Florianópolis, SC, 2004. Available:

https://geel.ufsc.br/files/2018/03/ProjetoPedag_2005_1.pdf. portuguese)

[8] J. Mamede. Manual of Electrical Equipment. $3^{\circ}$ Edition, LTC 2005 (in portuguese).

[9] K. R. Cotosck. "Protection of Electrical systems: A technical pedagogical approach”. 2007. Dissertation (Master's Degree in Electrical Engineering). Federal University of Minas Gerais - UFMG, Belo Horizonte, $2007 . \quad$ Available: https://repositorio.ufmg.br/bitstream/1843/BUOS8CZLET/1/kelly regina cotosckf.pdf. (in portuguese)

[10] ANEEL. Brazilian Electric Energy Agency. Report of Analysis of Forced Disconnections of the Transmission System. 2016 Edition. Available: https://www.aneel.gov.br/. (in portuguese)

[11] ANEEL. Brazilian Electric Energy Agency. Report of Analysis of Forced Disconnections of the Transmission System. 2017 Edition. Available: https://www.aneel.gov.br/. (in portuguese)

[12] ANEEL. Brazilian Electric Energy Agency. Report of Analysis of Forced Disconnections of the Transmission System. 2018 Edition. Available: https://www.aneel.gov.br/. (in portuguese)

[13] ONS. Brazilian Electrical System Operator. Available: http://ons.org.br/. (in portuguese).

[14] IBGE. Brazilian Institute of Geography and Statistics. Projection of the Population of Brazil and the Federative Units 2000, 2013 and 2016. Available: https://www.ibge.gov.br. (in portuguese).

[15] MEC. INEP. Brazilian Institute of Educational Studies and researches Anísio Teixeira. Undergraduate courses census. Technical repport from 2000, 2013, 2016 and 2018. Available: http://portal.inep.gov.br/web/guest/sinopses-estatisticas-da-educacaosuperior.(in portuguese).

[16] OIC. Observatory of innovation and competitiveness. Trends and Perspectives of Engineering in Brazil, 2015. São Paulo: Center for research support, observatory of innovation and competitiveness of the Institute advanced studies of the University from São Paulo. Available: http://homologa.oic.nap.usp.br/wpcontent/uploads/2017/03/Relatorio-Engenharia Data 20151-Ed4.pdf. (in portuguese).

[17] M. F. S. Alves, K. L. Mantovani, "Identification of the Engineering Academic Profile as a measure to combat evasion", ABENGE Brazilian Association of Engineering Education. Engineering Journal, v.35, n.2, p.26-36, 2016 (in portuguese). ISSN 0101-5001.

[18] MEC. Ministry of Education. Report of public and private universities registered and active. Available: http://www.mec.gov.br/. (in portuguese).

[19] N. R. Chaudhuri, P. Hines, R. Kavasseri, D. Ray, "Electric Power Engineering Education Resources: 2015-16 US and Canadian University Survey Results" Report Fron The Power and Energy Education Committee of The IEEE Power \& Energy Society. U.S, 2007.

[20] CONFEA/CREA. Federal Council of Engineering and Agronomy and Reginal Council of Engineering and Agronomy. "Regulation of the assignment of titles, activities, competences and professional fields of activity to the professionals registered in the Confea / Crea System for the purpose of supervising the professional exercise in the scope of Engineering and Agronomy" Resolution number 1,073. Brasília, DF, 2016. Available: http://normativos.confea.org.br/ementas/visualiza.asp?idEmenta=591 11. (in portuguese).

[21] MEC. Ministry of Education. National references of engineering courses. Available: http://www.mec.gov.br/. (in portuguese).

[22] Catholic University of Santa Catarina in Jaraguá do Sul. Mentions of the disciplines of Electrical Engineering. Jaraguá do Sul, SC, 2017. Available: http://www.catolicasc.org.br/jaragua-do-sul/wpcontent/uploads/sites/3/2015/03/Site Ementas-eRefer\%C3\%AAncias-EEL-JGS.pdf. (in portuguese).

[23] Q. Wang, Z. Tang, I. Knezevic, J. yu, G. Karady, "Power System Protection Education and Digital Relay Training Based on a Physical Platform", North American Power Symposium (NAPS),18-20 Sept. 2016.

[24] V. H Ferreira, M. Z. Fortes, M. Bouças. "Electrical power systems engineering undergraduate courses in Brazil: Academic and market perspectives", IJEEE - International Journal of Electrical Engineering Education. v. 53, p. 37-53. 2015. DOI: $10.1177 / 0020720915596752$.
[25] J. C. Gomez, C. Campelli, D. Tourn, J. C. Amatti, H. Rovere, "Need for Training of Engineers on Electrical Protections", CLADE Congress of the Americas of Electric Distribution. Argentina, 2016. p.1-6 (in spanish).

[26] J. McCalley, L. Bohmann, K. Miu, N. Schulz, "Electric Power Engineering Education Resources 2001-02 IEEE Power Engineering Society Committee Report.”, IEEE Trans. on Power Systems, v. 19, n. 4, Nov., 2004. DOI: 10.1109/TPWRS.2004.838578.

[27] G. Kindermann. Power System Protection. vol. I, II and III. $3^{\circ}$ Edition, Authors Edition, 2012 (in portuguese).

[28] A. C. Caminha. Introduction to Power System Protection. Blücher 1983. (in portuguese).

[29] C. R. Mason. The art \& science of protective relaying G\&E. Wiley 1956.

[30] W. A. Elmore. Protective relaying theory and applications. Marcel Dekker, Inc., 1994.

[31] J. Mamede, D. R. Mamede. Power System Protection. LTC, 2011 (in portuguese).

[32] J. A. Martínez-Velasco, J. Martín-Arnedo, F. Castro-Aranda "Modeling protective devices for distribution systems with distributed generation using an EMTP-type tool". Ingeniare. Rev. chil. ing., vol. 18 n. 2, 2010, pp. 258-273. ISSN 0718-3305.

[33] M. B. de las Casas, Y. Y. Boza. "Retos a las protecciones eléctricas en las redes de distribución con generación distribuida". Ingeniare. Rev. chil. ing., vol. 17 n. 1, 2009, pp. 101-107. ISSN 0718-3305.

Leocardia J. S. Kosuhovski is an Electrical Engineering student at the Federal Institute of Santa Catarina (IFSC), Florianopolis/SC, Brazil. Since 2018 is the main director of the IFSC Electrical Engineering Junior Enterprise (LAMP EJ).

Edison A. C. Aranha Neto received the Electrical Engineering degree from Federal University of Parana (UFPR), in 2003, Curitiba/PR, Brazil, and Master Eng. and Doctor Eng. degrees in Electrical Engineering from Federal University of Santa Catarina (UFSC), Florianopolis/SC, Brazil, in 2006 and 2012, respectively. Since 2013 he has been developing teaching/research activities at Federal Institute of Santa Catarina (IFSC), Florianopolis/SC, Brazil. His main fields of interest include power system planning, transmission and distribution systems. Since 2016 is the Electrical Engineering Course Coordinator.

Daniel Tenfen received the Electrical Engineering degree from University Center of Jaragua do Sul (UNERJ), in 2009, Jaragua do Sul, Brazil, and Master Eng. and Doctor Eng. degrees in Electrical Engineering from Federal University of Santa Catarina - UFSC; Florianopolis, SC, Brazil, in 2011 and 2015, respectively. Since 2016 he has been developing teaching/research activities at Federal Institute of Santa Catarina (IFSC), Florianopolis/SC, Brazil. His main fields of interest are electricity market simulation and regulation, power system planning and optimization, renewable generation, microgrids, smart grids and Demand Response Programs. Since 2018 is the Power Systems Technological Course Coordinator. 